Accepted Manuscript (AM) of Vullnetari, J. and King, R. (2008) 'Does your granny eat grass?' On mass migration, care drain and the fate of older people in rural Albania. Global Networks 8(2): 139-171 [DOI: 10.1111/j.1471-0374.2008.00189.x][accepted 12 July 2007; first published online 29 February 2008; published April 2008].

\title{
'Does your granny eat grass?' On mass migration, care drain and the fate of older people in rural Albania
}

\author{
JULIE VULLNETARI AND RUSSELL KING \\ Sussex Centre for Migration Research, University of Sussex, Brighton BN1 9SH, UK \\ J.Vullnetari@sussex.ac.uk \\ R.King@sussex.ac.uk
}

\begin{abstract}
Older people have been the main social casualties of the collapse of the Albanian communist system and the ensuing mass emigration of younger generations since 1990. Some have had to forage for survival on a near-starvation diet, making broth from grass and weeds. For others, remittances from emigrant children ensure adequate material well-being, but a loss of locally-based trans-generational care and of intimate family relations occurs. Rates of emigration have been highest in the southern uplands, where our fieldwork took place. Migration has been mainly to Greece, but also to Italy and elsewhere. Interviews with elderly 'residual households' - singles and couples - reveal stories of loneliness and abandonment. Cross-generational rupture of hitherto tight family structures is seen as emotionally painful because of the impossibility of enjoying mutual benefits of care sustained by geographical proximity. Profoundly upsetting is the denial of the practice of grandparenting, seen as their very raison d'être by the older generation. Cost of travel, visa regimes and emigrants' irregular status conspire to prevent international visits. Finally, we examine various strategies of overcoming the 'care drain' produced by this situation, one of which is for older people to try to join their migrant children and grandchildren abroad.
\end{abstract}

Keywords: ALBANIA, OLDER PEOPLE, MIGRATION, CARE DRAIN, TRANSNATIONAL CARE

[The Version of Record of this manuscript has been published and is available in Global Networks; April 2008; DOI: 10.1111/j.1471-0374.2008.00189.x]. 
Accepted Manuscript (AM) of Vullnetari, J. and King, R. (2008) 'Does your granny eat grass?' On mass migration, care drain and the fate of older people in rural Albania. Global Networks 8(2): 139-171

[DOI: 10.1111/j.1471-0374.2008.00189.x][accepted 12 July 2007; first published online 29 February 2008; published April 2008].

\section{Introduction}

The headline title of this paper may appear a little shocking. For sure, the Albanian state would not be happy with the notion that some of its most vulnerable citizens are reduced to a near-starvation diet. Nor, equally, are the relatives of the abandoned elderly likely to be pleased to be reminded of their incapability of caring for them. As for the old people themselves, it is an outspoken challenge to their pride. Our justification for using such a provocative phrase is twofold. First, we draw attention to a growing problem in post-communist Albania where the collapse of the old regime's paternalistic welfare state has combined with the mass emigration of working-age people to produce a new social phenomenon of abandoned and destitute elderly. Second, there is a sense of historical irony: a link to the days of Enver Hoxha when the people's stoicism against the imperialists' blockade was expressed by slogans about willingness to eat grass to survive rather than ask foreign powers for aid.

Tangible evidence for the elderly's extreme vulnerability comes from the Korçë Soup Kitchen Project, founded in the 1990 s by a small group of local and foreign volunteers who were concerned about the plight of elderly destitute people in this part of southern Albania. Relatively prosperous by Albanian standards, Korçë is a market town situated on an inland plateau surrounded by villages. Our fieldwork was conducted in this rural hinterland. Here is an eye-witness account of the coming of winter to the town by an English sponsor of the soup kitchen:

In early October we discussed the plight of the many destitute old people in the immediate vicinity ... Outside, the mountains were capped with snow ... now it will creep down the mountains and engulf the town

The local population was preparing for winter. The men were cutting mountain beech from the golden trees, returning with loads strapped to donkeys and mules ... The women were busy spinning wool from their own sheep or knitting socks. Ropes of tobacco leaves or small peppers hung out to dry under the eaves, garlic and onions were being strung 
Accepted Manuscript (AM) of Vullnetari, J. and King, R. (2008) 'Does your granny eat grass?' On mass migration, care drain and the fate of older people in rural Albania. Global Networks 8(2): 139-171

[DOI: 10.1111/j.1471-0374.2008.00189.x][accepted 12 July 2007; first published online 29 February 2008; published April 2008].

and early in the morning the mushroom pickers were rummaging on the hill. Children gathered fir cones and nuts ... The vegetable crops had done well and abundance filled the market and roadside stalls. Superficially a land of plenty.

But another group of people was eyeing the snow with apprehension. The destitute and semi-destitute elderly were preparing for winter as best they could without money. Cardboard, rags and newspaper were being gathered to line the derelict buildings where many of them squat. Bits of wood would be nailed over window spaces and trash bins were constantly excavated for anything useful.

The breakdown of the traditional extended family, emigration and youthful selfishness have resulted in many old Albanians now being reduced to eating grass, weeds or scavenging after the market closes ... [At the] soup kitchen ... up to 80 destitute old people are provided with a hot mid-day meal, five times a week ... Very obviously hungry and frequently dirty old people wolf it down ... ${ }^{1}$

This testimony sets the scene for our investigation. In a previous paper (King and Vullnetari 2006) we described pilot studies on older people's experiences and feelings of abandonment in both northern and southern Albania in a largely empirical account. The present paper progresses the analysis in two respects. First, it develops a theoretical thrust through exploring transnational elderly care and 'care drain', relatively new concepts in migration studies. Second, it includes results from a longer spell of fieldwork in four south Albanian villages and in the Greek city of Thessaloniki, the main destination for migration from this part of Albania.

\section{Key questions}

Three main research questions frame this paper. These are set within the context of Albania's sudden and disorganised exit from communism, and the mass outmigration which has occurred over the last decade and a half. Recent estimates 
Accepted Manuscript (AM) of Vullnetari, J. and King, R. (2008) 'Does your granny eat grass?' On mass migration, care drain and the fate of older people in rural Albania. Global Networks 8(2): 139-171

[DOI: 10.1111/j.1471-0374.2008.00189.x][accepted 12 July 2007; first published online 29 February 2008; published April 2008].

(Government of Albania 2005) indicate that the scale of this exodus - one in four of the total population, and maybe one in two of those aged 20-40 - is greater than that from any other former Eastern bloc country over the same time period. We scrutinise these figures in more detail later. Age selectivity in Albanian migration produces dramatic impacts on the demography and social conditions of the communities 'left behind', which are mainly rural. The mountainous nature of the terrain and the sparse road and transport network combine to foster extreme physical isolation of many communities. This has been exacerbated by the collapse of health and educational services in most rural districts.

According to the World Bank's study on vulnerable groups in Albania, there is strong evidence of increasing numbers of old people living alone and in dire conditions (1999: v, 7-8, 22-23). Elderly care institutions are few and inadequate and unprepared to meet demands from the growing numbers who are unsupported by children who have emigrated, or who do not have children. According to an expert witness in another World Bank study, 'One of the biggest problems that pensioners are facing is that ... their children have emigrated ... [and] are not in a position to help their parents or be by their side in their most difficult days. Emigration is creating ... pensioners that are lonely orphans' (de Soto et al. 2002: 46).

With these background perspectives in mind, here are our three major research questions; supplementary questions are also indicated.

1. What have been the emotional consequences of the mass emigration of young and early-middle-age adults on the older generations left behind? What do older people think about the emigration, and possible non-return, of their children? How do they cope with the reality that some, often all, of their children are living far away and are hence not 'there' to render care when needed? How do they feel about the fact that they do (or will) not live in close proximity to their grandchildren, and hence not have frequent contact with the next generation of their families?

2. Given that most emigrants are unlikely to return in the near future because their economic and social livelihood now lies in the destination country, what are the 
Accepted Manuscript (AM) of Vullnetari, J. and King, R. (2008) 'Does your granny eat grass?' On mass migration, care drain and the fate of older people in rural Albania. Global Networks 8(2): 139-171

[DOI: 10.1111/j.1471-0374.2008.00189.x][accepted 12 July 2007; first published online 29 February 2008; published April 2008].

prospects of the older generation migrating to join their children abroad? What are the rationales and problems attached to such a late-life migration?

3. The scale of Albanian emigration and its concentration in time contribute to a marked 'cohort effect' and therefore bring into sharp focus the removal of proximity-based cross-generational care. The older generation has suffered a sudden 'care drain' for which they, and the Albanian state, were totally unprepared. How can we conceptualise this care drain within the rapidlygrowing literature on transnational care?

\section{The elderly and transnational care}

We start by responding to the third question. The age-selection and cohort impacts of Albanian emigration since 1990 have geographically separated families across generations, rupturing the spatial proximity of family structures which had been in existence for generations and upon which cross-generational family care was based. Especially during the early years of migration, nearly all those who left were young males and (less so) young females; across many rural districts, the departure of almost an entire generation took place. True, remittances flowed back, but in other, non-material respects older people were left to fend for themselves in an economic and social environment stripped of any meaningful welfare structures.

The literature on the transnational care of the elderly in migrant situations is surprisingly limited and almost entirely recent. In past studies of international migration, a veil is drawn over this issue. For instance, in the 'great migrations' from Europe to North America in the nineteenth and early twentieth centuries, the fate of the elderly left behind was rarely mentioned, let alone studied in depth. Much the same can be said of the large-scale migrations within and into Europe in the decades following the Second World War. In both cases, the essentially economic character of these migrations, which were usually studied from the point of view of the destination societies, tended to result in the overlooking of emotional links back to parents in the homeland. We know, thus, almost nothing about the lives, experiences and feelings of the older generations who, in some cases, were never to see their children again. 
Accepted Manuscript (AM) of Vullnetari, J. and King, R. (2008) 'Does your granny eat grass?' On mass migration, care drain and the fate of older people in rural Albania. Global Networks 8(2): 139-171 [DOI: 10.1111/j.1471-0374.2008.00189.x][accepted 12 July 2007; first published online 29 February 2008; published April 2008].

Recently, however, a number of authors have started to document instances of long-distance elderly care amongst international migrants (see Baldassar and Baldock 2000; Baldassar 2007; Baldassar et al. 2007; Baldock 2000; 2003; Wilding 2006). These authors locate their research - which focuses especially on Italian and Dutch migrants in Australia - at the intersection of transnational migration, family studies and social gerontology. They note that, with very few exceptions, gerontological and family studies assume that cross-generational care requires geographical proximity. The preoccupation with spatial closeness can be seen as reflecting the reification of the notion of the family as a small-scale, private geographical domain. However, following the 'transnational turn' in migration studies, Baldassar et al. (2007) view international migration not as a one-off event leading from a source to a destination, but rather as a lifelong process of complex interactions between two or more places, in which family and community relations are set within transnational social and kinship spaces stretching often over great distances. Their research found extensive evidence of mutual care between transnational family members and various strategies for overcoming the barrier of distance. Indeed, in some cases, the very existence of the factor of long-distance separation was probably an incentive to establish regular and structured contact via letters, telephone calls, emails, text messages, financial assistance and return visits. Baldassar et al. (2007) also observe that the intensity of contact tends to increase at times of crisis such as illness or financial difficulty, as well as at certain key life events such as births, weddings, funerals, divorce etc.

Also important is the distinction between the desire and the capacity to transmit particular types of care. For instance, the desire to care depends to some extent on the 'health' of family relations: we cannot assume that 'happy families' are the norm (Baldock 2003). And the capacity to render care may depend on the financial resources available (e.g. for extended phone calls or return visits) and the freedom to travel across international borders. Both are also likely to be mediated by notions of what are culturally 'appropriate' care duties, which vary by migrant group and, to some extent, over time too. In the Dutch case, for example, high-quality state care for the elderly and a strong tradition of inter-generational independence diminish the material and practical demands on children; even in a situation of non-migration, 
Accepted Manuscript (AM) of Vullnetari, J. and King, R. (2008) 'Does your granny eat grass?' On mass migration, care drain and the fate of older people in rural Albania. Global Networks 8(2): 139-171

[DOI: 10.1111/j.1471-0374.2008.00189.x][accepted 12 July 2007; first published online 29 February 2008; published April 2008].

older people do not want to be reliant on their children for care, or live with them (Baldock 2003). Very different is the Italian case, where parents prefer and expect all forms of care, including personal care, to be provided by the family in one way or another. There is a tendency for the elderly in Italy to believe that, if they need to procure care services outside the family, then their family has somehow failed them. Hence there is an acute sense of duty on the part of the children to provide all the care needs of their parents in order to satisfy family and national norms of behaviour for 'good' sons and daughters. ${ }^{2}$ This seems to be a shared Mediterranean cultural feature and applies also to the Albanian situation.

Let us explore Baldassar's pioneering case-study of Italians in Australia in a little more detail, in order to assess its relevance to our research in Albania. This case involves migrants moving from 'San Fior', a small rural town in the mountains of northern Italy, to Perth, Western Australia. Most of the migrants left during the 1950s, 1960s and 1970s. Evidence was found of regular return visits (Baldassar 2001), which often had the character of a pilgrimage, and of extensive care-giving by migrants for their distant and increasingly elderly parents. Initially, the very act of migrating was seen as a contribution to the material care of non-migrant relatives, who were supported by gifts and remittances. Moreover, the initial intention was always to return - after about ten years, regarded as the typical length of time required to generate enough resources to re-establish back home. However, by this time, migrants had become settled in good jobs in Perth (some had set up their own businesses), and most had 'Australianised' children. Hence, whilst the emotional ties to parents and the home-town remained strong, the objective conditions for a definitive return had become problematic. Some tried an extended, provisional return for six months or so, but ended up by moving back to Australia.

During the first decade or so of emigration, when migrants' parents were still relatively young and fit (typically in their 50s and 6os), visits to Australia were made by the parents, financed by their children. Later, as parents became older and not up to making the long trip, the obligation shifted to the children to make visits. Those who were able to, visited regularly, perhaps once a year. Others timed their visits to coincide with particular events such as a godchild's wedding, their parents' $50^{\text {th }}$ wedding anniversary, or a serious illness or funeral. Taking their Australian-born 
Accepted Manuscript (AM) of Vullnetari, J. and King, R. (2008) 'Does your granny eat grass?' On mass migration, care drain and the fate of older people in rural Albania. Global Networks 8(2): 139-171

[DOI: 10.1111/j.1471-0374.2008.00189.x][accepted 12 July 2007; first published online 29 February 2008; published April 2008].

children back to meet their grandparents and other relatives was also seen as an important family obligation.

Baldassar and Baldock (2000) make three further interesting points about return visits. First, regular return visits enable 'hands-on' care to be given in a way that obviously cannot be administered at a distance. Second, the regular return visit is seen as a symbolic marker of a successful emigration which justifies the migrant's failure to repatriate. And third, visits home represent an important aspect of migrants' care for themselves - the best cure for homesickness being an opportunity to return to one's roots and breathe the 'native air' for a few weeks.

We have reviewed this important research by Baldassar and her colleagues because of the obvious similarity in geographical setting, Italy being a near-neighbour to Albania. There are some parallels in research findings, as we shall see, but there are several crucial differences which problematise the comparison. First, northern Italy, although poor in the early post-war years, was much better off then than Albania is today. Since the 1960s, moreover, Italy has become one of the world's wealthiest countries, whilst Albania remains arguably the poorest country in Europe, with a low standard of living and very poor services for older people. Second, there is a difference in the scale of migration. In the Italian case there were usually other family members left behind; in the Albanian case the emigration has often been wholesale, leaving elderly people as de facto 'orphans'. Third, Italian migration to Australia was legal, allowing migrants to return as and when they wanted (time and finance permitting), whereas much Albanian migration has been clandestine, making returns difficult and risky. Finally, the geographical distance between Italy and Australia is far greater than that between Albania and Greece and Italy, where most Albanians have emigrated. Yet, as we shall see presently, migrants' status is more important than distance in the Albanian context.

\section{Care drain}

Whilst the main conclusion of the research reviewed above is that distant care of elderly parents by emigrant offspring does take place, there is the other side of the coin. This focuses on the ways in which international migration deprives older people of such care, leading to a care drain. 
Accepted Manuscript (AM) of Vullnetari, J. and King, R. (2008) 'Does your granny eat grass?' On mass migration, care drain and the fate of older people in rural Albania. Global Networks 8(2): 139-171 [DOI: 10.1111/j.1471-0374.2008.00189.x][accepted 12 July 2007; first published online 29 February 2008; published April 2008].

The conceptual origins of the notion of care drain can be traced in four main fields. The first is the obvious parallelism to the much more widely debated brain drain, on which there has been a tradition of writing by economists and human capital theorists dating back to the 1960 s (e.g. Adams 1968; Glaser 1978). Albania, too, has suffered a major brain drain since 1990 (Gedeshi et al. 1999), but this is not the focus of the present paper.

Second, the term care drain has been used to describe the draining away of care in societies where demographic and economic changes have eroded the ability of relatives to provide care for the elderly. Moen and Forest (1995) were amongst the first to consider the care drain question in the light of changing family structures in Western societies; more recently Italy, Spain and Greece have been identified as classic areas where the 'traditional' family-based welfare model has withered under the combined influence of several processes (Bettio and Platenga 2004; Bettio et al. 2006; Ferrera 1996; Trifiletti 1999). Amongst such factors have been the following: the demographics of birth-rate collapse and rapid ageing of the population; the break-up of spatially contiguous extended families due to internal migration; greatly increased female participation in the paid workforce; the disappearance of local (i.e. native-born) care and support workers due to rising economic prosperity across all social classes; and the failure of the state or local authorities to step in to fill the 'care gap' beyond the payment of pensions and other, limited welfare-state provisions. For these Southern European countries the solution to the emerging care gap has been the recruitment of immigrant women (including Albanians) to supply a substitute form of in-house, family-type care.

Thirdly, in contradistinction to the national-bound nature of the original use of the term care drain, it is conceptually connected to the emerging literature on global care chains, defined as a 'series of personal links between people across the globe based on the paid or unpaid work of caring' (Ehrenreich and Hochschild 2003; Hochschild 2001). Here the role of the international migration of female carers is crucial and manifests itself in two closely-knit but, in another sense, opposing ways: on the one hand, immigrant women plug the care gap created by the economic, demographic and social changes noted above; on the other hand, in migrating to supply care to others, the women - from Albania, the Philippines, Peru and many 
Accepted Manuscript (AM) of Vullnetari, J. and King, R. (2008) 'Does your granny eat grass?' On mass migration, care drain and the fate of older people in rural Albania. Global Networks 8(2): 139-171 [DOI: 10.1111/j.1471-0374.2008.00189.x][accepted 12 July 2007; first published online 29 February 2008; published April 2008].

other poor countries - are depriving their own families and elderly parents of the care that they need and expect. 3

Dependency theory provides a fourth theoretical hook on which to hang some further comments on global care chains. Following Wallerstein's (1979) world systems approach, Ehrenreich and Hochschild (2003) introduce notions of care surplus (in the North) and deficit or drain (in the South) to signify the global mercantilisation of care in developed and underdeveloped regions linked by migration. Escrivá (2005: 4) acknowledges the importance of such structures, but also calls for a deeper and more nuanced account of the 'internal mechanisms ... of care drain ... on people's lives, conceptions and sentiments' and of the loss of 'emotional value and love' entailed in the mass migration of the economically active, who are also potentially the main care givers. Hence the need to focus not just on the migrants but also, even more, on those who receive (or are deprived of) care children, the elderly, the sick or disabled.

Our focus on the older generations in this paper responds to their previous omission in research on global care chains and to their marginal role in accounts of transnational migration generally. ${ }_{4}$ Although there has been a burst of recent publications on the later-life migration of wealthy North Europeans to the coastal resorts and rural landscapes of Southern Europe (Casado-Díaz et al. 2004; Gustafson 2001; King et al. 1998; 2000; O'Reilly 2000), very little specific effort has been devoted to researching the increasing participation of the elderly in transnational migratory spaces opened up initially by younger generations. Two key processes urgently need studying: first, what happens to the elderly who are left behind by their migrant children? Second, how widespread is the growing trend for older people to migrate to join their emigrant-worker children abroad? These are the two remaining questions we address, focusing on the Albanian case.

\section{Migration in Albania and its spatio-temporal impact on older people}

During the 45 years in which the communist regime held Albania in its authoritarian grip, international migration was strictly forbidden. Internal movements, too, were tightly regulated and urbanisation was kept artificially low, so that towns grew more slowly than the overall population. Once the barriers to migration came down, 
Accepted Manuscript (AM) of Vullnetari, J. and King, R. (2008) 'Does your granny eat grass?' On mass migration, care drain and the fate of older people in rural Albania. Global Networks 8(2): 139-171 [DOI: 10.1111/j.1471-0374.2008.00189.x][accepted 12 July 2007; first published online 29 February 2008; published April 2008].

Albania experienced massive population mobility, both internally towards Tirana and Durrës, respectively the national capital and the country's main port city, and to other countries. Emigration was overwhelmingly to Italy and Greece, neighbouring countries which were easy to access by boat across the neck of the Adriatic or over the mountains to the south (King 2003). Much of the early migration, until the mid-late 1990s, was clandestine and hence reliable statistics did not exist.

Later, the 2001 census (which indicated a migratory loss of 710,000 during 19892001 INSTAT 2004a: 34) and subsequent estimates by the Albanian government, based partly on destination country records, yielded a 'stock' of 1 million emigrants in 2005, including 600,000 in Greece, 250,000 in Italy, and smaller, but significant numbers in the US, UK, Canada, France, Belgium and Germany.

The scale of this emigration and its concentration in a short period are unprecedented in Europe in modern times (Fakiolas 1994). The country moved almost instantaneously from introverted closure to mass out-migration. In the single year 1991 it is thought that as many as 200,000 Albanians migrated to Greece. Van Hear (1998: 119) described the flight of Albanians after 1990 as 'a new migration order'. Driven by the need to survive after the economic and political chaos of the country's brutal exit from communism and the collapse of the state-run employment system, the exodus was characterised by Barjaba and Perrone (1996: 133) as a 'migration of economic refugees'.

Both Italy and Greece initially welcomed the first arrivals of Albanians in 1990 and 1991. Fleeing a crumbling communist state which had been closed off for decades, the early border-crossers were viewed as Adriatic or Balkan 'brethren' and treated with a kind of exotic curiosity (Zinn 1996). Very quickly, however, another discourse took hold, ruthlessly managed by the Greek and Italian media and by politicians eager to capitalise on anti-immigrant sentiment. This discourse condemned Albanians as criminals and undesirables, and built on earlier histories of Greco-Albanian antagonism and Italo-Albanian colonialism (Konidaris 2005; Mai 2003). Subsequently, other processes improved their socio-economic standing in the two countries, notably increased language fluency, accessing better jobs and achieving family reunion; also very important have been the periodic regularisations (in Italy in 1995, 1998 and 2002, in Greece in 1998 and 2001) which have markedly 
Accepted Manuscript (AM) of Vullnetari, J. and King, R. (2008) 'Does your granny eat grass?' On mass migration, care drain and the fate of older people in rural Albania. Global Networks 8(2): 139-171

[DOI: 10.1111/j.1471-0374.2008.00189.x][accepted 12 July 2007; first published online 29 February 2008; published April 2008].

shifted the balance in favour of legally present immigrants (Bonifazi and Sabatino 2003; Hatziprokopiou 2003; King and Mai 2004).

Turning back to Albania, Figure 1a shows the spatial pattern of emigration abroad, based on the census residual method, for the period 1989-2001.5 This can be interpreted with reference to the spatial mesh of Albania's 36 districts (Figure 1b) and the general geography and topography of the country (Figure 1c). The pattern is clear: emigration has had its greatest relative impact in the south of the country, in districts which are rural and hilly or mountainous. In some districts, emigration has 'removed' more than a third of the 1989 population; and in two southern districts, more than a half. Emigration from this part of Albania has been overwhelmingly to Greece; in addition, older emigration links to the United States and Australia have been resuscitated.

Figure 2 shows the old-age dependency ratio - persons aged $65^{+}$as a percentage of those aged 15-64 - by commune/municipality. The map shows that virtually all the high ratios are in the southern quarter of the country, where some rural communes score ratios of 50 per cent and above, indicating a considerable predominance of older people in areas which have been massively affected by out-migration.

Both INSTAT and the World Bank predict progressive ageing of the Albanian population over the next 20 years, especially in the south where the combination of high out-migration, internal as well as external, falling fertility, and low mortality means that the ageing phenomenon will be most pronounced. According to a recent World Bank study, the population aged over 65 will grow by 60 per cent during the period 2000-2025, and the elderly's share of total population will increase from 7 to 13 per cent of the total (World Bank 2007: 7). The population pyramid for 2021, compared to that for 2001, will show particularly sharp increases in the age band 5574, especially for females (INSTAT 2004c: 38 ). This suggests that, at least at a demographic-statistical level, the social phenomena of elderly care and abandonment that we address in this paper will become increasingly relevant in the future. 
Accepted Manuscript (AM) of Vullnetari, J. and King, R. (2008) 'Does your granny eat grass?' On mass migration, care drain and the fate of older people in rural Albania. Global Networks 8(2): 139-171 [DOI: 10.1111/j.1471-0374.2008.00189.x][accepted 12 July 2007; first published online 29 February 2008; published April 2008].
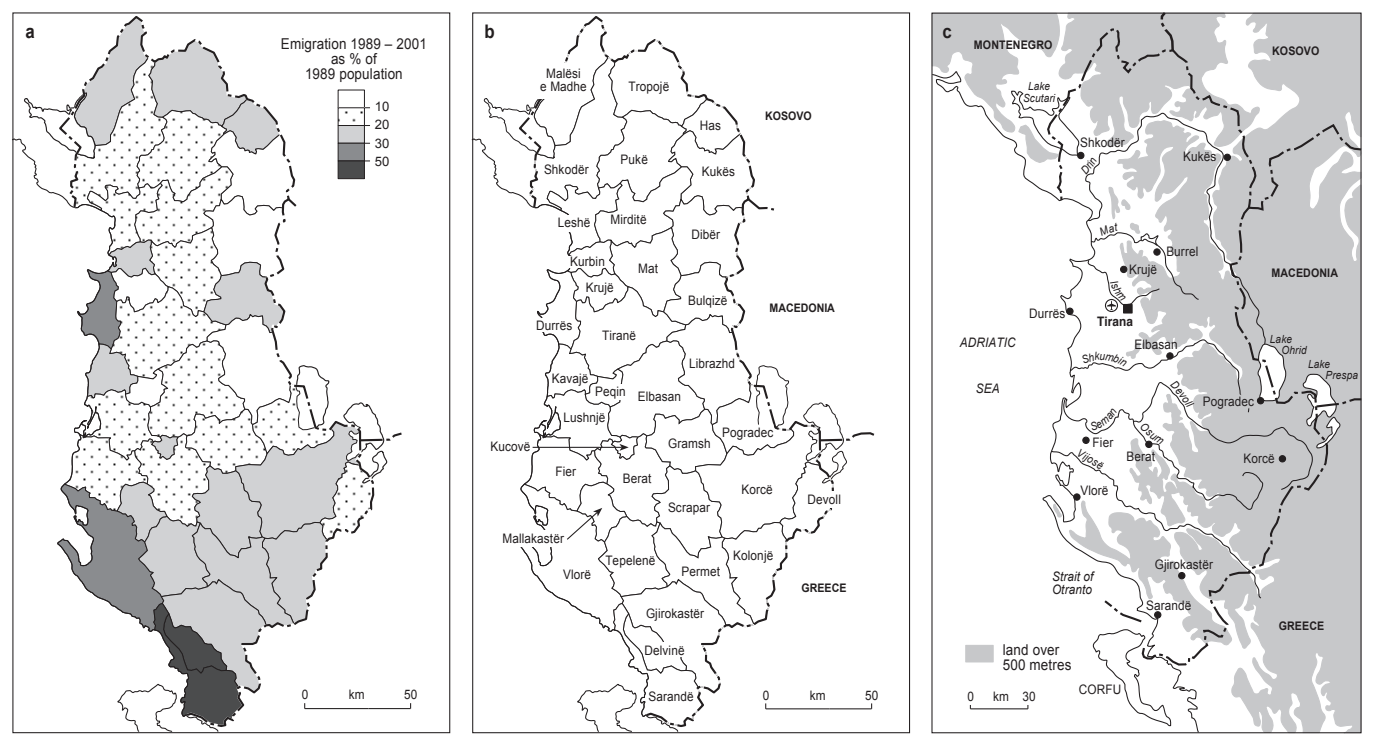

Figure 1 Albanian emigration in its regional setting

Source: partly based on data from Carletto et al. (2004). 
Accepted Manuscript (AM) of Vullnetari, J. and King, R. (2008) 'Does your granny eat grass?' On mass migration, care drain and the fate of older people in rural Albania. Global Networks 8(2): 139-171 [DOI: 10.1111/j.1471-0374.2008.00189.x][accepted 12 July 2007; first published online 29 February 2008; published April 2008].

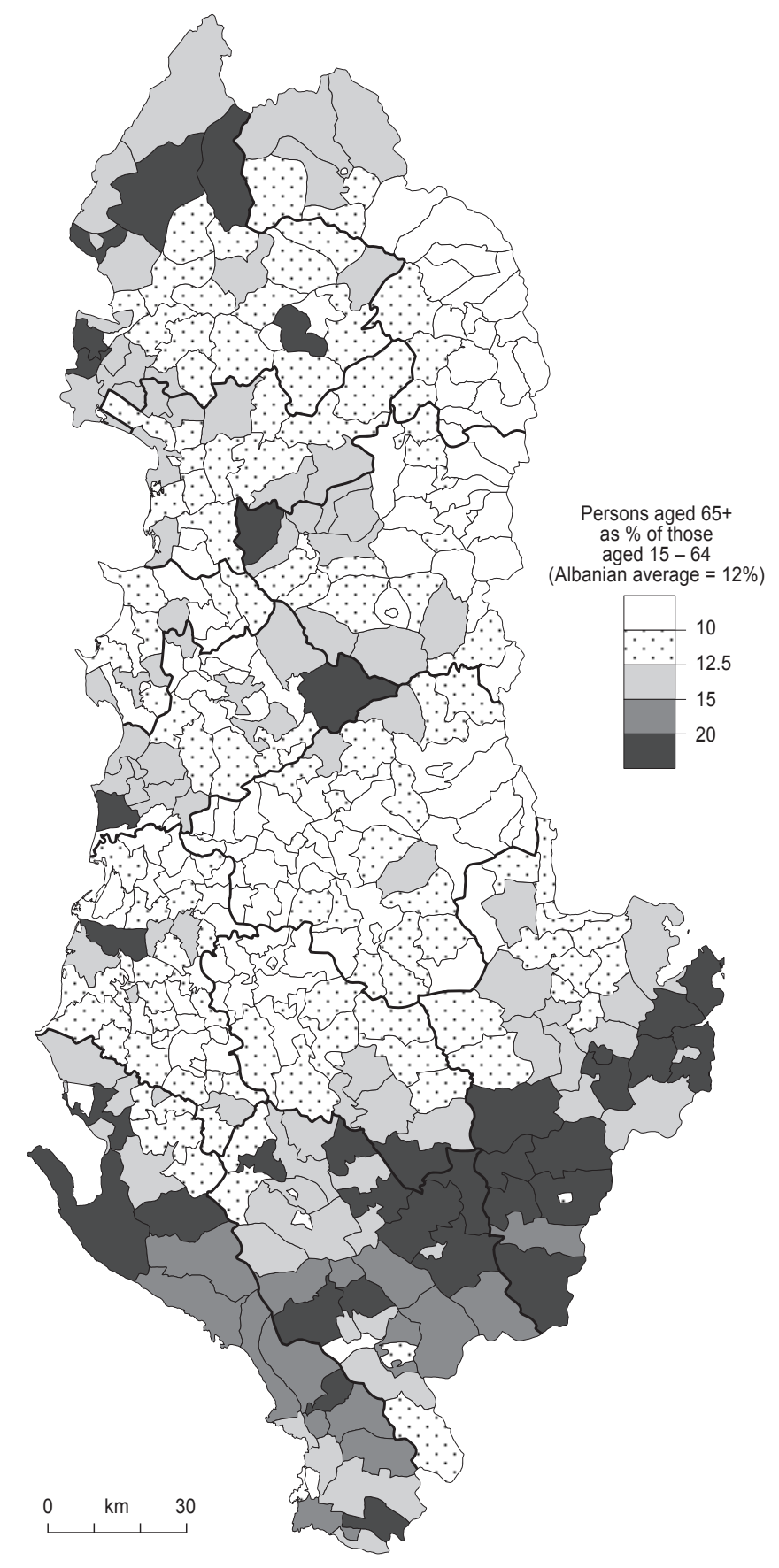

Figure 2 Albania: old-age dependency ratio 2001 Source: INSTAT (2004b: 19). 
Accepted Manuscript (AM) of Vullnetari, J. and King, R. (2008) 'Does your granny eat grass?' On mass migration, care drain and the fate of older people in rural Albania. Global Networks 8(2): 139-171

[DOI: 10.1111/j.1471-0374.2008.00189.x][accepted 12 July 2007; first published online 29 February 2008; published April 2008].

\section{Field sites and methodology}

Field research in two main sites provides the data for our analysis of the impact of out-migration on older people:

- Interviews $(n=38)$ in a cluster of four small villages in south-east Albania. All interviewees were selected as older village residents with adult children currently living abroad. Some of the households also had children who had migrated internally to Tirana or other important towns. These interviews were carried out in 2004 (pilot study) and 2005 (the main fieldwork period).

- Interviews $(n=23)$ with Albanian migrants from the four villages who had relocated to the Greek city of Thessaloniki. Some of these were family members of interviewees in the villages. In Thessaloniki our focus was both on the care practices of migrants towards their elderly relatives back home, and on older people who had followed their children to Greece. These interviews were done in 2006.

In the 61 interviews, there were 87 interviewees. Except for people who lived on their own in the villages - mainly widows - it often proved impractical to interview individuals. Many interviews were with couples, and a few with larger family/household units. In such settings, there was a tendency for the male to act as spokesperson for the couple or family group, especially in village interviews with older males present. This behaviour, which reflects patriarchal gender relations typical of Albanian families, risks silencing the female voice. But we should not exaggerate the impact of this on the interviews, many of which were conducted in a good-humoured and lively atmosphere, with various family members contributing information and opinions. Other interviewees, however, especially elderly couples and widows, became sad and emotional, reflecting the disturbing and personal themes exposed.

All names of interviewees are pseudonyms; likewise the villages' names are not revealed, to ensure confidentiality. Reflecting their experience under the communist regime, many older people in Albania feel uneasy about being interviewed and indeed are unaccustomed to the notion; they are especially wary of giving opinions on topics 
Accepted Manuscript (AM) of Vullnetari, J. and King, R. (2008) 'Does your granny eat grass?' On mass migration, care drain and the fate of older people in rural Albania. Global Networks 8(2): 139-171

[DOI: 10.1111/j.1471-0374.2008.00189.x][accepted 12 July 2007; first published online 29 February 2008; published April 2008].

that could be construed as relating to the government or local authorities, fearing persecution. For this reason, as well as respect for the general principles of research ethics, the interviews avoided such sensitive topics, focusing instead on everyday activities, the elderly respondents' feelings about the migration of their children, their thoughts and plans for the future, and their concerns over health and care issues. When permission was given, interviews were taped and then transcribed and translated. In the minority of cases where interviewees did not want to be recorded, detailed notes were taken during and after the interview. ${ }^{6}$

Finally, a few words about the four villages, which together constitute a commune. They have a combined population of around 5,000, according to commune records. This is an over-estimate of the number of people actually present in the villages because of the widespread practice of temporary migration, mainly to Greece. Moreover, it is in the municipality's interest not to quantify the extent of the population loss, for fear of losing resources and being downgraded. The 2001 Census counted just over 3,600 inhabitants, including more than 500 pensioners.

\section{Albania's 'lost generation'}

Let us now look at how the mass emigration of young adults has impacted on those left behind in the villages. Everyone comments on the mass-scale departure of most of the young men and women from the district, and the consequent changes in the demographic landscape. A middle-aged mother of a migrant son describes the situation thus: 'Most young people are in Greece. My son is there, someone else's nephew, brother, father. There are no young men here'.

What began as a shuttle or seasonal form of migration to Greece in the early and mid-1990s has now turned to semi-permanent migration. Women and children have joined husbands and fathers through the regularisation and family reunion schemes eventually offered by Italy, Greece and other countries, and now live together with them abroad. They only come to visit their parents in the village during the holiday periods; however, for those without a 'legal' status in the host country, such return visits are next to impossible.

The older people left in the villages find it hard to adjust to such living arrangements. A strong dilemma is present in their narratives. Broken-hearted by 
Accepted Manuscript (AM) of Vullnetari, J. and King, R. (2008) 'Does your granny eat grass?' On mass migration, care drain and the fate of older people in rural Albania. Global Networks 8(2): 139-171 [DOI: 10.1111/j.1471-0374.2008.00189.x][accepted 12 July 2007; first published online 29 February 2008; published April 2008].

this separation, they regret the loss of normal family life as they have known it, and the cross-generational physical proximity and reciprocal care-giving that tradition would prescribe. Yet, a sense of fatalistic realism is adopted: under the difficult conditions of economic chaos and collapse in post-communist Albania, there was no alternative. They see the emigration of their children as a necessary family strategy of survival and remittances as the only source for sustaining a modest measure of prosperity.

... we worked hard and suffered all our lives. We only had one pair of clothes. Now, we have plenty. So, there are negative sides, because we miss them a lot, but there are also positive sides. When our children tell us that they are well, we have a great satisfaction. We want them to do well and prosper (Halime, 58).

Next, an interview with a couple in which the financial benefit of remittances is again acknowledged, but also the lack of frequent physical contact with children and grandchildren. Note the gendering evident in this quote - how it is the emigrant son who is 'privileged' by being missed, for sons remain as part of their parents' close family and therefore bear some responsibilities for their care in old age, whereas daughters pass into the domain of their in-laws' household upon marriage, and their care duties are diverted from their own parents to their husband's parents.

For a parent the absence of a son is very hard, and missing the children [i.e. grandchildren] is also very hard. We miss them a lot, but our son has his work there (Gurazie, 61)... and [said jokingly] we need the money! (Fari, 66).

The above quotes put a brave face on the transnational reality of emigration and separation, one even managing a joking tone. These interviewees are the 'young old', in their 50 s and 6os. All have children abroad - in Greece, Italy, America etc. - but they remain in decent health and are physically capable of making visits to them. 
Accepted Manuscript (AM) of Vullnetari, J. and King, R. (2008) 'Does your granny eat grass?' On mass migration, care drain and the fate of older people in rural Albania. Global Networks 8(2): 139-171 [DOI: 10.1111/j.1471-0374.2008.00189.x][accepted 12 July 2007; first published online 29 February 2008; published April 2008].

Other interviewees were the 'old old', in their 70s and older. They spoke with more emotion, and pathos, about sacrificing their own needs and wishes for the sake of their children making a better life abroad. They felt more isolated and had less capability of making foreign trips. An elderly father describes the situation:

If we were a little younger, we would not have experienced these difficulties [at this point tears fill his eyes and he cries silently - it is very unusual for an Albanian man to cry in a public situation]. But things are becoming more and more difficult for us. We are getting older, we cannot work, we need help now. But, we can't spoil things for our children (Sabri, 73).

In some respects life for the elderly in the villages continues as it did before. Even when children send remittances, the older villagers continue to work diligently on their land and cottage gardens, according to their health and strength. They live frugally, as they always have (there was no choice during the communist years), and try to survive on their own produce and the meagre pensions from their labour during 'the regime'.

But working has also therapeutic benefits: keeping busy leaves them less time to ponder the absence of their children and grandchildren. When evening comes, however, loneliness makes its presence felt even more: surrounded by photographs of their offspring, they become sad and emotional. Ylvere (69) lives with her 73-year-old husband; their only son lives with his family in Canada. Her voice trembles as she speaks:

When we are by ourselves in the evening and sit next to the fire, I can't tell you how difficult it is... We just cherish the picture of our granddaughter. I look at the pictures one after another, that of our son, our daughter-in-law... I can't speak any more about my son, I miss him so much... 
Accepted Manuscript (AM) of Vullnetari, J. and King, R. (2008) 'Does your granny eat grass?' On mass migration, care drain and the fate of older people in rural Albania. Global Networks 8(2): 139-171 [DOI: 10.1111/j.1471-0374.2008.00189.x][accepted 12 July 2007; first published online 29 February 2008; published April 2008].

This time of day is even more difficult for those who are on their own - usually widowed women. Refije, aged 76, lives alone since her husband died six years ago:

It's difficult for old people at my age to be on their own. It's OK during the day, because I have things to do, but the most difficult part is in the evening, when I come home to an empty house.

Struggling through life, with loved ones far away, these older people described themselves over and over again as the 'lost generation'. Their tough life during the communist regime ${ }^{7}$ was followed by hardship and family separation in sudden and ruthless post-communist economic collapse and restructuring. Adjustment to the market economy and the new system of family relations linked to it (King and Vullnetari 2003: 17-19) did not come easy at this stage of their lives. Used to living in relatively large family units, in close proximity to their children and parents even after marriage, older people's sense of abandonment is increased as reunion with their children slowly transforms from conviction to forlorn hope. The prospects of their children's return from emigration begin to look remote, ${ }^{8}$ and their own chances of joining them abroad are reduced by highly bureaucratic visa regimes and old age.

The painful realisation that their children will probably not return to resettle comes from assessing the objective economic difficulties of creating a decent livelihood in rural Albania, and the reality that their children have settled down in their respective host countries. Furthermore, when emigrants from rural areas return, they are more likely to relocate in Albania's major urban centres such as Tirana and Durrës, where better economic prospects can be found, leading thus to a process of rural-to-urban migration via emigration abroad.

In the following quotes about issues of (non-)return, the first is a simple illustration about the ambivalence of the future, and the growing commitment of children to put down roots abroad:

They say they won't return for the time being ... but ... I don't know about later ... The eldest son has built a house there [in Greece] (Donika, 65). 
Accepted Manuscript (AM) of Vullnetari, J. and King, R. (2008) 'Does your granny eat grass?' On mass migration, care drain and the fate of older people in rural Albania. Global Networks 8(2): 139-171 [DOI: 10.1111/j.1471-0374.2008.00189.x][accepted 12 July 2007; first published online 29 February 2008; published April 2008].

The second quote, from another set of parents with sons in Greece (their daughters live elsewhere in Albania), reveals that the topic is too awkward even to broach:

We haven't had these discussions, because I don't feel comfortable asking them these things. We hardly see them once a year and to have these conversations [about a possible return] then is not very nice... (Sejdin, 58).

One of the other major issues standing in the way of return for many migrants is the future of their own children, who are integrated into the host-country school system, having been born abroad or taken there at an early age. For many of these young children, Greece or Italy (or elsewhere) is the only home they have ever known. Sulo (73) lives with his wife (72) in one of the villages, their son and his family live in the United States, while their daughters are married and living with the families of their husbands. As a member of the 'middle generation', Sulo's son faces a serious dilemma between the responsibility to care for and be with two sets of kin: his parents in the village, and his young daughters who are settled in the USA. Sulo's son has chosen to stay in the US for the sake of his daughters' future, while trying to combine 'distant care' for his elderly parents on the other side of the Atlantic. But, return trips from the USA are time-consuming and expensive, especially for whole families. Sulo explains:

At the beginning he thought of living and working in America for a time and then ... returning to live with us. But the difficulty is with the children. ...They are growing up in different environments.

Sulo's family is split in half and none of its members can enjoy the benefits of a multigenerational unit living in close geographical proximity: the older generation are not able to exercise hands-on grandparenting and the emotional benefits that derive from this; the middle-generation migrant son and daughter-in-law are not able to benefit from this childcare, and in turn are not able to provide hands-on care for the parental generation in their old age; and the youngest generation, the young daughters in this 
Accepted Manuscript (AM) of Vullnetari, J. and King, R. (2008) 'Does your granny eat grass?' On mass migration, care drain and the fate of older people in rural Albania. Global Networks 8(2): 139-171 [DOI: 10.1111/j.1471-0374.2008.00189.x][accepted 12 July 2007; first published online 29 February 2008; published April 2008].

case, are not benefiting from the care and emotional link with their grandparents, and the wider cultural link to their ancestral home.

\section{Barriers to care-giving and examples of care deprivation}

The broken intergenerational chain of care and the lack of close contact with the younger generations, evidenced by Sulo's family, are repeatedly identified by the village elderly as the most negative aspects of their lives as 'orphan pensioners'. True, long-distance care does take place in the ways that Baldassar et al. (2007: 276) describe - hands-on support during visits, financial help via remittances and presents, and moral and emotional support through telephone calls, video-tapes, photographs etc.). However, the meaning attached to care by our older interviewees was overwhelmingly dominated by notions of physical proximity and simply 'being together'. Here we wish also to affirm an important point which challenges the conventional framing of the transnational care-giving debate as a situation in which it is the (potential) receivers of long-distance care (young children or old people "left behind' by the departing emigrants) who are the vulnerable ones suffering 'care drain'. Our field data clearly demonstrate that one of the most distressing aspects of Albania's experience of the quasi-forced migration of such a large share of the youngadult cohorts is that older people have been denied the right to be care-givers, especially to their grandchildren. All the interviewees who had grandchildren broke down in tears as they spoke of how much they missed being with them. Jorgiia (70) is a widow who had looked after her grandson for two years whilst the child's parents were in Greece. She is overcome by the memory of this:

I miss the little ones. Particularly my grandson who lived with me here for two years ... Here, I still have his little cardigan tucked away [starts crying] ... I had my dear little Spiro here ...

Other interviewees broadened the discussion about denied grandparenting to a linguistic and cultural dimension, counterbalancing the economic benefits of migration against the human price that has to be paid: 
Accepted Manuscript (AM) of Vullnetari, J. and King, R. (2008) 'Does your granny eat grass?' On mass migration, care drain and the fate of older people in rural Albania. Global Networks 8(2): 139-171 [DOI: 10.1111/j.1471-0374.2008.00189.x][accepted 12 July 2007; first published online 29 February 2008; published April 2008].

We don't even know our grandchildren ... The little girl, she is 5 years old, doesn't know how to say hello to us. We can't say hello to her [she only speaks and understands Greek] ... Emigration is good for the standard of living that it has created, it's good from the financial point of view. But when it comes to feelings and the emotional impact, it has had a destructive outcome. I don't need my son to send me money, I need the person himself... (Rakip, 78).

The last part of this quote is interesting because it reveals that for Rakip (and several other interviewees too), their personal and emotional needs have taken over from financial exigencies, unlike the early years of migration when family survival was paramount.

The lack of opportunity to play the role of active grandparenting is lamented by many older parents. Zarife (74) and her husband (76) feel that they are now approaching the last years of their lives, yet they have totally missed out on active grandparenting as their only son and his family have been living in Greece for the past 14 years. Employing a variety of agricultural metaphors, she described their lives as 'bare and dry', likening themselves to a tree that does not yield fruit or a field that does not produce crops. Without grandchildren close by to nurture and watch grow up into the next generation of the family, their lives have lost their true purpose.

Others, however, stress their sense of abandonment by their children and their need of receiving care. Pertef (72) feels that the time has come for him to give up working; yet, with his only son away in Greece, he has to continue to work the land without any help:

I need my son to be here now. I need my daughter-in-law here, or my grand-daughter. To make me a coffee, to bring me something I need ... Is this a good thing that I have to go and hoe the fields? I am 72 years old, I have worked all my life ...

Many interviewees used locally-rooted metaphors to describe their situation. Crying throughout the interview, Sali (70) and Sanie (68) said they felt like stones left in the 
Accepted Manuscript (AM) of Vullnetari, J. and King, R. (2008) 'Does your granny eat grass?' On mass migration, care drain and the fate of older people in rural Albania. Global Networks 8(2): 139-171 [DOI: 10.1111/j.1471-0374.2008.00189.x][accepted 12 July 2007; first published online 29 February 2008; published April 2008].

middle of the road'. Two other interviewees independently referred to the old people left behind as 'logs' - i.e. deadwood, lying around, useless with nothing to do.

As a final cri de cœur about loneliness, separation and partial abandonment, we return to the case of Sulo, whom we quoted earlier, and his wife Myryban:

Sulo: ... we feel their absence, because age takes its toll, this is the thing that bothers us ... the distance

Myryban: Well, at least we have these blessed telephones. They call us once a week [from the USA]. When that day comes, we go crazy. I know that they're going to call and I don't go out at all ...

Sulo: [the distance] is the problem for us, because if we have a problem we can't tell them [so as not to worry them], not only because it's costly for them [to travel], but they wouldn't be able to get here in time. Everything would be finished [meaning if one of them gets ill and dies]. This hurts us a lot.

Myryban: Let's hope we come to an end as we are now, without having to become ill ...

Sulo: Well, that's not going to happen, so forget that ...

Several interpretative comments can be made about the above exchange. First, a contrast can be drawn between the more pessimistic, dogmatic tone of Sulo compared to the more optimistic, conciliatory view of his wife. This gendered contrast in relation to migration reflects to some extent the patriarchal authoritarianism present in virtually all Albanian households and has been noted in similar dual interview exchanges in other studies (King et al. 2006). Second, there is the in-built assumption that it is the duty of the son in America to telephone and take the lead in care-giving, rather than the couple's two daughters in Albania. As noted already, daughters, through marriage, become part of their husbands' families and therefore part of the support system for the husbands' parents, not their own. Third, there is the admission, which also emerged in other interviews, that the old people are concerned 'not to bother' their children with problems they cannot easily solve or do anything about. 
Accepted Manuscript (AM) of Vullnetari, J. and King, R. (2008) 'Does your granny eat grass?' On mass migration, care drain and the fate of older people in rural Albania. Global Networks 8(2): 139-171 [DOI: 10.1111/j.1471-0374.2008.00189.x][accepted 12 July 2007; first published online 29 February 2008; published April 2008].

The sense of abandonment felt by elderly villagers also extends to their views of Albanian politicians and the state. Although we did not ask questions on this topic, some interviewees expressed anger at what they saw as a corrupt and ineffective administration, and in particular with the irresponsibility and avarice of politicians and others with power. The state was also blamed by many interviewees for not defending the right of Albanians to travel to see their children abroad. Even greater criticism was vented on other governments for their repressive control of crossborder movement and reluctance to grant visas. This anger was especially harsh and justified - in the case of the Greek government where inefficient and discriminatory bureaucracy constitutes a frustrating stumbling-block to the ability to travel freely between neighbouring countries (see Psimmenos and Kassimati 2003). The irony here is that labour mobility has been well-documented as a form of economic symbiosis which benefits both countries: flexible and willing workers are supplied to key sectors of the Greek economy which would not function efficiently and competitively without them; and wages and remittances enable Albanian families to survive, either as migrants in Greece or as family members who stay behind to take care of the house, the land and other relatives (Baldwin-Edwards 2004).

Ferit and Mynefe have a son and a daughter, both married and living in Thessaloniki, only four hours away by car. And yet, the barrier of the border and the difficulty of getting travel permits continually block their ability to visit their children and grandchildren. Their children experience inordinate bureaucratic delays in getting the requisite documents so that they can travel to Albania and then be allowed to re-enter Greece, whilst Ferit and Mynefe face similar difficulties in getting visas from the Greek consulate in Korçë:

They don't give papers to the oldest people. Now, in case you miss your children, and you want to go and visit them for a week or two, they [the Greek consular authorities] don't give you visas, they don't give visas at all (Mynefe, 64).

Nor is any allowance made for special or emergency situations, such as a mother's wish to be with her daughter when she gives birth, or a parent's funeral: 
Accepted Manuscript (AM) of Vullnetari, J. and King, R. (2008) 'Does your granny eat grass?' On mass migration, care drain and the fate of older people in rural Albania. Global Networks 8(2): 139-171 [DOI: 10.1111/j.1471-0374.2008.00189.x][accepted 12 July 2007; first published online 29 February 2008; published April 2008].

[In our village] there have been occasions of death, when the son has not been able to come and bury his father or his mother. So, even on such a day, the daughter or son cannot come and throw a handful of earth on the grave of their parent who cared for them all their lives. This is injustice. There is a law that talks about human rights, these international organisations or whatever they are. What sort of human rights do these organisations give? Nothing is given to the people (Ferit, $70)$.

\section{The other side}

So far, we have discussed the issues of loneliness, care giving and receiving, and family relations from the point of view of the older parents who remain in the villages of origin. Our research also involved interviews with young and middle-aged migrants in Thessaloniki. With a metropolitan-area population of around 1 million, Thessaloniki is the closest major employment market on 'the other side' of the border. Interviewing the migrant generation also gives us an 'other-side' perspective on family and care dynamics to that narrated by the older generation. 9

The emigrant generation was in most cases fully aware of their responsibilities towards their parents and elderly relatives. Indeed this was a major part of their reason for emigrating - to support family members back home. But emigration changes the shape of family structures, especially the relationship between young couples and their parents, and we need, first, to put these issues in context.

In Albanian society children have been historically considered as a type of social insurance in old age. Tradition dictated (and to a large extent still does, particularly in rural areas) that the youngest son (and his wife) look after his parents in their old age - indeed the youngest son is referred to in Albanian parlance as 'the son of old age'. In addition, patriarchal gender relations linked to household economics within the virilocal Albanian family have implications for care expectations and transmission..$^{10}$ Post-communist transformation and emigration have impacted heavily on these norms, and ways are sought to cope with the new order of things for instance when the youngest son has himself emigrated, when intra-familial conflicts arise or in the case of daughters-only families. 
Accepted Manuscript (AM) of Vullnetari, J. and King, R. (2008) 'Does your granny eat grass?' On mass migration, care drain and the fate of older people in rural Albania. Global Networks 8(2): 139-171 [DOI: 10.1111/j.1471-0374.2008.00189.x][accepted 12 July 2007; first published online 29 February 2008; published April 2008].

Several interviews with older people in the villages and younger migrants abroad illustrate some of these situations. Dashamire (75) is a widow (her husband died 14 years ago) living with and caring for her 8-year-old grand-daughter, from her younger son's first marriage. Now this son has re-married and emigrated to Thessaloniki, where he has a new family. Dashamire's older son is married and lives in Korçë. Her four daughters are all married and live either locally, in different parts of south-east Albania, or in Tirana. Interestingly, when discussing care responsibilities, Dashamire does not even mention her daughters, because their care duties are to their own families and to their husbands' parents. The problem for Dashamire is that the location of her sons is the opposite of what it should be according to Albanian custom. In the interview, Dashamire related how her older son usually comes to visit every 4-5 days, but on the last occasion it has been 10 days:

I told him off this time because it had been 10 days. 'But you are not with me', he said [meaning you should be looked after by the youngest son and not by me]. I told him: 'I am with you as long as he [the youngest son] is over there [Greece]'.

Dashamire also described how her younger son has asked her to join him and his new family in Greece (thereby fulfilling his traditional duty of care, albeit not in the ancestral home). In Thessaloniki, she would be able to look after all the grandchildren and do the housekeeping, thereby releasing her daughter-in-law to go into paid employment. In the end, Dashamire did not go. It appeared that her son's wife did not like the idea of the step-daughter going to live with them, and perhaps also the idea of her mother-in-law trying to run their lives.

In this story there is a certain measure of disagreement between the mother-inlaw and the daughter-in-law. The expectations and wishes of these two people, who also represent two different generations, are in conflict with one another. This impinges on a whole range of possible care relations - between grandmother and grand-daughter, grandmother and other grandchildren, mother and son, son and daughter, mother and step-daughter, and, conditioning them all, between mother-inlaw and daughter-in-law. The son is in the middle, trying to make everyone happy. 
Accepted Manuscript (AM) of Vullnetari, J. and King, R. (2008) 'Does your granny eat grass?' On mass migration, care drain and the fate of older people in rural Albania. Global Networks 8(2): 139-171 [DOI: 10.1111/j.1471-0374.2008.00189.x][accepted 12 July 2007; first published online 29 February 2008; published April 2008].

Another example concerns an elderly couple who have no sons, only daughters. Rexhep (73) and Feruze (65) live on their own, their five daughters all married and living away from the village - in Korçë, Durrës, Greece and Australia. The old couple live mainly from subsistence farming and pensions which barely cover Feruze's medicines and Rexhep's cigarettes. The washing-machine bought by the daughter in Greece stands out in the spartan-looking house ('this is Enver Hoxha's furniture' meaning furniture from the time of the communist regime), whose walls are adorned with photographs of their children and grandchildren. The daughter in Korçë comes now and again to help with farming, but as far as remittances are concerned, there are no expectations; it was emphasised that 'they [daughters] are with their husbands now' and 'send you money only if the husband agrees to it'. As for the future, Feruze said:

We haven't really discussed this, but we have agreed on this: as long as we are both alive we will stay here. If one of us is left behind, then of course, one can't live on their own. Probably [the one who is left] will go and live with the third daughter [who lives in Korçë] ... They all [the daughters] tell us to sell it all now, move in with them and take it easy for the few years we have left. But how can we go and stay with the son-in-law?

This highlighted sentence is revealingly indicative of the marked gendering of elderly care within the Albanian family. Life in the household of a daughter has been traditionally thought of as less appropriate or attractive than in that of the son, for the reasons given earlier. As young people have moved away from their parental home, either abroad or to an Albanian town, they have been able to create a household independent, to some extent, of whatever material things the parental home might have had. Often, both husband and wife have worked to contribute to the migrant household economy, and as such it is widely considered as the enterprise of both. This perspective emerged strongly from the interviews in Thessaloniki: 
Accepted Manuscript (AM) of Vullnetari, J. and King, R. (2008) 'Does your granny eat grass?' On mass migration, care drain and the fate of older people in rural Albania. Global Networks 8(2): 139-171 [DOI: 10.1111/j.1471-0374.2008.00189.x][accepted 12 July 2007; first published online 29 February 2008; published April 2008].

Now you have to look at it this way, that here in Greece both the husband and the wife are working [i.e. in paid employment] towards the household economy. You can't say I am going to the household of my son-in-law, or my son-in-law will look after me. This is the sweat [i.e. work] of both of us in this household (Mirela, 35).

Mirela, too, comes from a daughters-only family where her parents are left alone in Albania; all her sisters are away and married, either elsewhere in Albania, or in Greece or Switzerland. She laments that she has no brothers who would take on the duty of care for her parents. On the other hand, she and her husband have his mother living with them, which makes it even more economically and socially unviable for her parents to join them. However, she insists that, ideally, she would prefer to be living alone with her husband and children, and have her parents or mother-in-law living next door. She continues:

A daughter-in-law and a mother-in-law can never get along with one another. This is from my experience and that of my friends. The young will never agree with the old ... When there are two women in one house, in one kitchen, the old want things to be done as they used to be in the old days, and the young will want things done as easily as possible. So of course there will be arguments.

Mirela expresses what numerous Albanian migrant women feel and think about how they prefer the living arrangements between the generations. Many other testimonies bear this out. One more, from a migrant woman in her late $40 \mathrm{Os}$, Thessaloniki:

I know that I am free when I am living only with my husband and children. Then I have peace of mind. Even when I argue with my husband, my mother-in-law is not there to listen to it ... We are now used to this way of life [as emigrants] ... For instance, I want to be wearing shorts around the house. This wouldn't bother my son, because 
Accepted Manuscript (AM) of Vullnetari, J. and King, R. (2008) 'Does your granny eat grass?' On mass migration, care drain and the fate of older people in rural Albania. Global Networks 8(2): 139-171

[DOI: 10.1111/j.1471-0374.2008.00189.x][accepted 12 July 2007; first published online 29 February 2008; published April 2008].

he is used to it, but it would bother my mother-in-law, because she belongs to another generation.

There are at least two ironies in the situations described above. The first is that these opinions about the undesirability of living with Albanian mothers-in-law and the generally negative comments about the older generations are expressed by Albanian migrant women who might be living in the same house as a Greek older person, for whom they are providing care. The second irony follows closely from this: the elderly care performed by Albanians (and other nationalities) in Greece is at the risk of lessening the care given to their own elderly parents back in Albania.

It is, of course, the economic incentives, driven by the care crisis for older people in Greece, where the family welfare model has broken down, which makes such living arrangements attractive for migrants. Live-in carers get rent-free accommodation, and the wife has long-term full employment. In rural areas of Greece, the husband might also be employed to look after the garden, farmland or small business whilst his wife takes care of the employer's domestic domain, thereby making the whole arrangement financially sound and relatively secure, even if much of the work is likely to be done 'off the books'. Sometimes the migrant couple gets to inherit a cottage in return for such live-in care and support. In urban areas of Greece, it is considered convenient for all concerned when the migrant couple lives in the same apartment as the older Greek couple or individual being cared for. The irony, however, again bears repeating: live-in care is provided to one elderly household at the expense of the migrant's own elderly relatives. The parallels with classic braindrain are obvious.

There is one other aspect of care management that emerged from the fieldwork in Thessaloniki. Albanian migration to this city (and to Greece as a whole) consists more and more of young and early-middle-age couples with children (Hatziprokopiou 2003; Pratsinakis 2004). In a segmented but flourishing informal-sector labour market, there is plenty of employment available for Albanians: for men in construction, factory work and small-scale services; for women in domestic and care services. In order to maximise income-earning potential, both husband and wife must work. This creates the problem of childcare, for which four solutions exist: the 
Accepted Manuscript (AM) of Vullnetari, J. and King, R. (2008) 'Does your granny eat grass?' On mass migration, care drain and the fate of older people in rural Albania. Global Networks 8(2): 139-171

[DOI: 10.1111/j.1471-0374.2008.00189.x][accepted 12 July 2007; first published online 29 February 2008; published April 2008].

children can be kept in Albania in the care of their grandparents (two cases of this arrangement were mentioned earlier); the migrants' parents (or perhaps just the mother) can move to Greece to provide on-the-spot childcare; parents arrange working hours between themselves so they do not overlap and leave young children alone in the house for the hours that neither of them can be at home; or the migrants can seek private childcare (in the absence of access to state nurseries). Regarding the last of these alternatives, we noted an interesting new trend in Thessaloniki, which is for older migrant women to provide this service at rates which are more acceptable than the expensive Greek private system. Liza (28), who lives with her young family in Thessaloniki, told us about the arrangements she made for her 5 -year-old daughter so that both she and her husband could take paid work. The couple made a deal with an Albanian migrant grandmother in her mid-6os who is already looking after her own three grandchildren. They pay her $€_{5}$ per day and the child goes to the house of the carer. This rate is considered financially acceptable for both sides: the grandmother gets some extra cash for care work she is doing anyway, and the mother is released for paid work.

\section{Older people as migrants}

The prospects of the younger-generation migrants returning to Albania are uncertain, as noted already. Whilst some authors, such as de Zwager et al. (2005: 58-61), predict a wave of return in the fairly near future, other studies, including our own, suggest that most migrants are unlikely to return, at least not before they themselves retire.

What strategies are used by Albanian multi-generational families to deal with this situation? In particular, what are the prospects of the older generation migrating to follow their children abroad? This is the final of our trilogy of research questions to be considered.

Several of the interview narratives presented above include references or hints to a follow-the-children strategy, and other evidence suggests that it is indeed a noteworthy practice. The 2001 Census found 10 per cent more men than women in the 60-69 years cohort (INSTAT 2002: 28-30): this indicates an emigration of older women, who may well be widows. ${ }^{11}$ And Reilly et al. (2005: 3), based on analysis of a question in the Albanian Living Standards Measurement Survey about whether 
Accepted Manuscript (AM) of Vullnetari, J. and King, R. (2008) 'Does your granny eat grass?' On mass migration, care drain and the fate of older people in rural Albania. Global Networks 8(2): 139-171 [DOI: 10.1111/j.1471-0374.2008.00189.x][accepted 12 July 2007; first published online 29 February 2008; published April 2008].

respondents had considered emigration, found that although on average men were more likely to have considered migrating abroad than women, for older cohorts the relationship is reversed. This is the phenomenon known in Albania as 'migrating grannies' - where older women follow their sons and (less often) daughters abroad to look after grandchildren so both parents can work.

With their children settled abroad, the older generation faces three choices:

- staying at home in the village, trying to manage on their own and receiving visits from their children and grandchildren every now and then;

- emigrating to join their children abroad, or perhaps relocating within Albania to join a child who has migrated internally;

- dividing their time between the home village and the new home of their children.

The first option is mainly taken by the older parents, in their 70s and 80s - the 'older old' - who are likely to be the most frail and vulnerable, and thus more likely to be care recipients than care-givers. What they miss above all, as already noted, is their 'natural right' to be grandparents with their grandchildren living close at hand: this aspect of care-giving, nurturing the new generation, is denied by the emigration of their children, with devastating emotional consequences.

Despite their age, most of this group are involved in farming and gardening. Although separated from their children, they feel most comfortable at home in their village, where they can live amongst friends and peers, calling upon the support of relatives or neighbours when needed. Having spent a large part of their lives under the communist regime when mobility was highly restricted, and movement abroad forbidden, they feel they are too old, set in their ways, and locally rooted to contemplate emigration (and sometimes even internal migration) at this late stage in their lives. They feel they 'belong' only in their village:

It seems very hard at this elderly age to leave our homeland ... We don't want to neglect the house of our son so that it falls into disrepair. At the 
Accepted Manuscript (AM) of Vullnetari, J. and King, R. (2008) 'Does your granny eat grass?' On mass migration, care drain and the fate of older people in rural Albania. Global Networks 8(2): 139-171 [DOI: 10.1111/j.1471-0374.2008.00189.x][accepted 12 July 2007; first published online 29 February 2008; published April 2008].

moment things are going OK, but we don't know how long it will continue.

Life-time familiarity and the stronger sense of social cohesion amongst older people in the village also make many of them reluctant to reunite with their internalmigrant children who live in Albanian towns. Dashamire had gone to live with her son in Korçë for nine months 'but it seemed like 19 years'. Another widow had spent several months with her son in Elbasan but vowed never to go back for such a long period as she had found it so difficult, cooped up in a flat in a block, and missed the informal friendliness of the village.

There are also younger parents who are resistant to migration. Flutur (56) and her husband have a son and a daughter, both living with their families in Greece. Asked for her thoughts on emigration to join her son's family, she replied:

... we prefer our homeland ... We were born here and we grew up here. We are elderly now, we want our homeland, we want our rest and peace here. And also, at this age, we don't feel like going elsewhere. I don't feel like going to the city for instance, to move from here to another town, in Albania. We wouldn't want to do that. We might have to, because we would follow our son ...

The situation becomes much more problematic when one of the partners dies, particularly if this is the wife, as it is considered extremely difficult for an old man in Albania to look after himself. The case of Mazar (76) and Donika (65) illustrates this perspective rather well, and also throws up another variable, that of the greater willingness of one partner (usually the female) to migrate than the other. Mazar and Donika have seven children (two sons and five daughters), all abroad in Greece, except for one son who recently moved from Greece to Italy. Donika is willing, even keen, to join her son in Greece, whereas Mazar is not. Donika explains:

Mazar doesn't want to go there [to Greece] ... because of the language ... he can't learn it now, he's 76 ... If I die he will go there of course, 
Accepted Manuscript (AM) of Vullnetari, J. and King, R. (2008) 'Does your granny eat grass?' On mass migration, care drain and the fate of older people in rural Albania. Global Networks 8(2): 139-171 [DOI: 10.1111/j.1471-0374.2008.00189.x][accepted 12 July 2007; first published online 29 February 2008; published April 2008].

because who will look after him? Will they [their children] leave their children and move here? One of us will go there: if my husband dies, I will go; if I die first, he will have to go there, he can't stay here on his own.

One further factor may keep the 'younger old' at home: their care responsibilities to their own parents. Parents aged in their 50s or 6os may have migrant children aged 20 s and 30 s abroad, but in addition they might have their own parents in their $70 \mathrm{~s}$ and $80 \mathrm{~s}$ in the village, for whom they have physical and emotional care responsibilities. When asked if she would join her son in Greece, Tefta (57) replied: 'grandma [meaning her mother-in-law] is here, we can't leave her alone'. Ksanthi (66) faced a similar dilemma. With sons in Greece and Italy, she and her husband live alone in the village. But they are trapped: 'My mother-in-law has had Alzheimer's for seven years, I couldn't leave her alone'. In such cases, it is the wife who bears the major burden. Ksanthi's husband is also sick, recovering from a serious kidney operation. She has to look after her husband, her mother-in-law, the family cow and the apple orchard.

The second option is taken mainly by the younger old. These parents are still physically able to give much-needed support to their emigrant children by providing child care for them, thereby freeing the female migrants to join the workforce. Sometimes they will also take up paid employment themselves, according to their free time, skills and abilities. In such cases women will typically be looking after older Greeks in need of personal care, or the children of other Albanian migrants as we saw earlier, whilst men may do light construction tasks, work in catering or as guards for building complexes. Ramiz (55) and his wife live in Thessaloniki with their youngest son, aged 24, who is desperately trying to get a work visa for Greece. Their case illustrates the difficulty noted earlier of establishing fully-documented regularisation and family reunification in Greece. Their eldest son lives in the USA and the family hopes that, once he is naturalised, he can arrange for the whole family to go there.

Serjan (65) and Burbuqe (63) are more advanced in their process of reunification with their son in the United States. Like the previous case, they have two sons, one in Thessaloniki and one in the US. Since their sons emigrated, they have lived on their 
Accepted Manuscript (AM) of Vullnetari, J. and King, R. (2008) 'Does your granny eat grass?' On mass migration, care drain and the fate of older people in rural Albania. Global Networks 8(2): 139-171 [DOI: 10.1111/j.1471-0374.2008.00189.x][accepted 12 July 2007; first published online 29 February 2008; published April 2008].

own, surviving on remittances, modest pension income, and some subsistence farming. They have never visited their sons. They have just become grandparents, since their son and daughter-in-law in Greece have just had their first child. Burbuqe explains their plans:

Now they [son and daughter-in-law in America] have arranged all the documents for family reunification. Our daughter-in-law is coming over in September and she will go to the [US] consulate [in Tirana] ... The other son has also wanted us to visit him, but it has been more difficult [obtaining a visa] for Greece.

This case throws up two problematic issues which were recurrent throughout our interviews and which are fundamentally characteristic of the Albanian emigration situation. We came across many cases where the wish of the parents to join their children abroad, at least for a 'trial' migration, and sometimes just for a family visit, was frustrated by visa difficulties. The irony evident in the case of Serjan and Burbuqe above was that, whilst they are able to get a family reunification for the United States, they are not able to get a visa to visit their new grandson over the mountains four hours away by road. So far they have only heard his gurgles over the phone.

The second issue raised by the interview with Serjan and Burbuqe is that, if parents join one of their children abroad, they will be isolating themselves from other children and grandchildren who may be in other countries, and from relatives in Albania. It is very common for Albanian migrant siblings to be in several different countries. This is a characteristic feature of Albanian migration and derives from the large size of Albanian families and from the ways in which clandestine and legal migration channels often lead to multiple and different destinations. As the migrant family fragments amongst two, three or more destinations in North America, Europe and perhaps elsewhere, family cohesion may break down and the management of care may become more difficult.

Finally, the third option listed above is the one preferred by the majority of physically able older villagers with migrant children. Most wanted the right to be able 
Accepted Manuscript (AM) of Vullnetari, J. and King, R. (2008) 'Does your granny eat grass?' On mass migration, care drain and the fate of older people in rural Albania. Global Networks 8(2): 139-171 [DOI: 10.1111/j.1471-0374.2008.00189.x][accepted 12 July 2007; first published online 29 February 2008; published April 2008].

to visit their children freely, for several weeks at a time, perhaps longer, and particularly for special occasions such as births, holidays etc. Like the second option, this one too is dependent upon being able to obtain entry to the migrant's host country. It has been generally difficult obtaining visas from the various embassies and consulates of these countries, and even where they have been granted they are usually for one entry only and a limited stay. This is not enough for a mother who wants to be with her daughter at or after the birth of a child. Feruze (65) wanted to support her daughter in Greece during a difficult childbirth but was not able to obtain a visa:

My daughter gave birth to two children there. She was in the hospital, and had a caesarean. They sent me the invitation and the guarantee several times ... I was rejected. Who knows why? The policeman [guard at the consulate] kicks you out of the door immediately and there is nothing you can do about it.

Ability to travel to the host country is also dependent upon the status of the emigrant children in these countries. In cases where the migrants hold long-term stay permits, and particularly when they have been able to naturalise, the process has been much more accessible. Such has been the case of emigrants in the USA and Canada, where many migrants from Albania have been able to obtain long-term working visas through the Green Card Diversity and the Highly Skilled Migrant programmes respectively. The parents of these emigrants have been able to obtain visas of up to six months, followed by the possibility sometimes of family reunification (see King and Vullnetari 2006: 803-08). More problematic is the situation of emigrants in Greece. The regularisation processes there are not well administered, which often results in migrants lapsing into irregularity through no fault of their own (Fakiolas 2003). The inefficiency of the Greek authorities and their aggressively poor behaviour is also evident at the border checkpoints - as both authors have had occasion to observe.

One group that is able to come and go into Greece with greater freedom is the ethnic-Greek minority of southern Albania. A few of our interviewees had the special 
Accepted Manuscript (AM) of Vullnetari, J. and King, R. (2008) 'Does your granny eat grass?' On mass migration, care drain and the fate of older people in rural Albania. Global Networks 8(2): 139-171 [DOI: 10.1111/j.1471-0374.2008.00189.x][accepted 12 July 2007; first published online 29 February 2008; published April 2008].

identity card that this ethnic-Greek status brings. Niko and Kristina, both in their 70s, have multiple entry visas because of their Greek ethnic origin. ${ }^{12}$ They often go and visit their two sons, who are now in their 50s, as well as their grandchildren, one of whom herself has children (Niko and Kristina's great-grandchildren). Hence, Niko and Kristina live transnationally - or rather translocally - between their village, where they generally spend the summers, and Thessaloniki, where they spend the winter. Kristina does household chores when they are with their sons' families, Niko takes the great-grandchildren to the crèche or to the park. Their sons work in construction, and their daughters-in-law do daycare and cleaning jobs for elderly Greeks. Although their sons have asked them to join them in Greece, the parents prefer the village. In Kristina's words:

We can't stay there: it's too hot [in summer], we don't speak the language - it's a difficult age we're at now ... When I'm there, I would help cook the meals, clean the house and do other household jobs. Women have to bear all the burden.

Kristina and Niko then engage in a dialogue about the complementarity of their lives and preferences in the two places, inter-cutting one another with bits of information about the merits of the village and their journeys back and forth:

Our problem is solved. We go there whenever we feel like it, when we miss them. We have been there many times ... But it is very hot there [in summer] ... When we go there we stay indoors all day, because there's nowhere to go ... Here it is very different, even the food is better ... It's not far away, just three hours by car ... Yes, but it's also expensive, $€ 100$ for the taxi ... The bus is also good, but you can't take lots of stuff with you on the bus, whereas when we go there by car we fill up the boot ... our clothes, some food for them, flour from home ... Our plan is to stay here [in the village] because we are old now ... it's only when we come here that we feel ourselves. 
Accepted Manuscript (AM) of Vullnetari, J. and King, R. (2008) 'Does your granny eat grass?' On mass migration, care drain and the fate of older people in rural Albania. Global Networks 8(2): 139-171 [DOI: 10.1111/j.1471-0374.2008.00189.x][accepted 12 July 2007; first published online 29 February 2008; published April 2008].

\section{Conclusions}

In our introduction we spoke about the soup kitchen in Korçë. We interviewed the local priest in charge of its management who explained that most of the nearly 100 people who came for the free meal each weekday were women; men felt ashamed to be seen there, whereas women used church visits as cover. He went on:

There are many people today who are abandoned by their migrant children. From what I know of those who come here, none of them have the support of their children ... People come and ask me, 'Please Father, can you give me 1000 lek, because I can't pay the electricity or water bills. My son is in Greece, Italy, Germany, and he hasn't sent me any money'. Sometimes people live in self-made shacks, or simply outside, or in the bunkers [the concrete shelters built by the Hoxha regime] ... It's OK in the summer, when it's warm, but when the winter comes, it is very difficult. There are also those who are abandoned but do not come here because they are ashamed.

This testimony confirms how dire the situation of some elderly parents is, particularly in towns. Since 1990 urban areas have undergone dramatic population changes due to internal migration. One of our female migrant interviewees in Thessaloniki expressed her worries for her parents left behind in one such urban area:

My mother is 64 whereas my father is 71 years of age. Now they have health problems, like most people of their generation. I am worried about them because they are alone. Even the neighbours who used to live in the same flat next door, when I lived there, are not there anymore. They have left and others have come in their place, strangers, people we don't know. So my parents do not have any support from anyone, they only have each other. If they need to go to a hospital or something like that, there is no-one there to help them. 
Accepted Manuscript (AM) of Vullnetari, J. and King, R. (2008) 'Does your granny eat grass?' On mass migration, care drain and the fate of older people in rural Albania. Global Networks 8(2): 139-171

[DOI: 10.1111/j.1471-0374.2008.00189.x][accepted 12 July 2007; first published online 29 February 2008; published April 2008].

In the villages, the sense of abandonment is softened somewhat by the support of kin and neighbours. Even though the population of the villages is shrinking, the sense of community and neighbourly solidarity is still there; indeed it is probably reinforced amongst the old people because they feel they are the only ones left. Support ranges from help with farming and house maintenance to assistance in cases of ill-health or emotional turmoil. These safety networks are stronger in the compact villages of southern Albania than in the dispersed settlements of the north (King and Vullnetari 2006). Their existence has arguably eased the pressure that would otherwise have been exerted on the state social services. There are only five residential homes for the elderly in the whole of Albania, run by the Ministry of Labour, Social Affairs and Equal Opportunities. They - and some NGO-run daycare centres - are all located in the major cities. Social care for the fragile elderly, such as home visits from social workers or nurses, or live-in care etc., are non-existent in rural areas.

Hence our original research question about the impact of emigration on the fate of older people left behind needs to be refined in several ways: the causal link is not that direct and simple. Equally important has been the suddenness of the emigration flow and of the contemporaneous collapse of the state welfare system since 1990. The comparison between urban and rural environments reveals a double contrast. The very limited state services for the elderly that exist are concentrated in a few cities, and are totally insufficient to cope with the needs of a newly-mixed urban population that has few support mechanisms of its own - giving rise to the sad scenes described in the 'soup kitchen' quote at the start of the paper, which also reflect the individualism and anonymity of urban life. The villages, on the other hand, have even fewer public services for older residents, but this is somehow compensated for by the existence of some neighbourly support and no shortage of accommodation.

But there are other possibilities, linked especially to internal migration from the villages to the outskirts of Tirana, and to the fact that return migration, to be sustainable, at least for the time being, seems mainly to be oriented to the capital. Qemal (72) and Nevrez (65) live alone in the village: their only daughter is in the USA and their only son is in Milan, both married and with families. Two options present themselves. One is to join their daughter in America, once she has acquired US 
Accepted Manuscript (AM) of Vullnetari, J. and King, R. (2008) 'Does your granny eat grass?' On mass migration, care drain and the fate of older people in rural Albania. Global Networks 8(2): 139-171 [DOI: 10.1111/j.1471-0374.2008.00189.x][accepted 12 July 2007; first published online 29 February 2008; published April 2008].

citizenship. This move may take some time, but is made more socially feasible by the fact that their son-in-law's parents have died and so they do not take precedence. They cannot move to their son in Milan because he and his family of four only rent a small flat and there is an Italian regulation about the ratio of people to square metres in the case of immigrant family reunification. However, this son is actively contemplating a return to settle in Tirana, where he has already built a house with his earnings from work in Greece and Italy. Other relatives of Qemal - his brother, cousins, etc. - have also built houses on the same area of land in Tirana so there will be a family regrouping there when the son decides to return. This case shows how the family proves to be a resilient and flexible institution, able to adapt to and accommodate the new conditions of external and internal migration brought about by economic necessity, and providing a locationally fluid safety-net of mutual care and support - in the village, abroad (in the US, but not in Milan) and in Tirana.

To sum up, our case study responds to Escrivá's (2005) call for a more in-depth analysis of the loss of the emotional value of care and love which mass migration of the economically active produces, and for specific attention to be paid to the experiences and feelings of the elderly non-migrants. Our study stands in contrast to previous work on migration and transnational care which has tended to be migrantcentred. Our emic perspective on the older generations left behind has allowed these older voices, which are usually rather silent in transnational migration research, to emerge in their full range and combination of rationality and emotion.

\section{Acknowledgments}

Parts of the fieldwork were financed by an ESRC postgraduate studentship in Migration Studies held by Julie Vullnetari. The authors also acknowledge some helpful comments by three referees on this paper.

\section{References}

Ackers, L. and Dwyer, P. (2002) Senior Citizenship? Migration and Welfare in the European Union. Bristol: Policy Press.

Adams, W., (ed.) (1968) The Brain Drain. London: Collier-Macmillan. 
Accepted Manuscript (AM) of Vullnetari, J. and King, R. (2008) 'Does your granny eat grass?' On mass migration, care drain and the fate of older people in rural Albania. Global Networks 8(2): 139-171 [DOI: 10.1111/j.1471-0374.2008.00189.x][accepted 12 July 2007; first published online 29 February 2008; published April 2008].

Arrehag, L., Sjöberg, Ö. and Sjöblom, M. (2005) Cross-border migration and remittances in a post-communist society: return flows of money and goods in Korçë district, Albania. South Eastern Europe Journal of Economics, 3(1): 940.

Arrehag, L., Sjöberg, Ö. and Sjöblom, M. (2006) Post-communist cross-border migration in southeastern Albania: Who leaves? Who stays behind? Journal of Ethnic and Migration Studies, 32(3): 377-402.

Baldassar, L. (2001) Visits Home: Migration Experiences between Italy and Australia. Melbourne: Melbourne University Press.

Baldassar, L. (2007) Transnational families and aged care: the mobility of care and the migrancy of ageing. Journal of Ethnic and Migration Studies, 33(2): 27597.

Baldassar, L. and Baldock, C. (2000) Linking migration and family studies: transnational migrants and the care of ageing parents, in Agozino, B., (ed.) Theoretical and Methodological Issues in Migration Research: Interdisciplinary, Intergenerational and International Perspectives. Aldershot: Ashgate, 61-89.

Baldassar, L., Wilding, R. and Baldock, C. (2007) Long-distance care-giving: transnational families and the provision of aged care, in Paoletti, I., (ed.) Family Caregiving for Older Disabled People: Relational and Institutional Issues. New York: Nova Science Publishers, 201-27.

Baldock, C. (2000) Migrants and their parents: care-giving from a distance. Journal of Family Issues, 21(2): 205-24.

Baldock, C. (2003) Long-distance migrants and family support: a Dutch case-study. Health Sociology Review, 12(1): 45-54.

Baldwin-Edwards, M. (2004) Albanian emigration and the Greek labour market: economic symbiosis and social ambiguity. South-East Europe Review, 7(1): 51-66.

Barjaba, K. and Perrone, L. (1996) Forme e grado di adattamento dei migranti di cultura albanese in Europa (Italia, Grecia, Germania), 1992-1995, in Barjaba, K., Lapassade, G. and Perrone, L., (eds) Naufragi Albanesi: Studi, Ricerche e Riflessioni sull'Albania. Rome: Sensibili alle Foglie, 123-62. 
Accepted Manuscript (AM) of Vullnetari, J. and King, R. (2008) 'Does your granny eat grass?' On mass migration, care drain and the fate of older people in rural Albania. Global Networks 8(2): 139-171

[DOI: 10.1111/j.1471-0374.2008.00189.x][accepted 12 July 2007; first published online 29 February 2008; published April 2008].

Bettio, F. and Platenga, J. (2004) Comparing care regimes in Europe. Feminist Economics, 10(1): 85-113.

Bettio, F., Simonazzi, A. and Villa, P. (2006) Change in care regimes and female migration: 'care drain' in the Mediterranean. Journal of European Social Policy, 16(3): 271-85.

Bonifazi, C. and Sabatino, D. (2003) Albanian migration to Italy: what official data and survey results can reveal. Journal of Ethnic and Migration Studies, 29(6): 967-95.

Carletto, G., Davis, B., Stampini, M. and Zezza, A. (2004) Internal Mobility and International Migration in Albania. Rome: FAO, ESA Working Paper 04-13.

Casado-Díaz, M.A., Kaiser, C. and Warnes, A.M. (2004) Northern European retired residents in nine southern European areas: characteristics, motivations and adjustment. Ageing and Society, 24(3): 353-81.

Castaldo, A., Litchfield, J. and Reilly, B. (2005) Migration and poverty in Albania: what factors are associated with an individual's predisposition to migration? Journal of Southern Europe and the Balkans, 7(2): 157-73.

de Rapper, G. (2005) Better than Muslims, not as good as Greeks: emigration experienced and imagined by the Albanian Christians of Lunxhëri, in King, R., Mai, N. and Schwandner-Sievers, S., (eds) The New Albanian Migration. Brighton: Sussex Academic Press, 173-94.

de Soto, H., Gordon, P., Gedeshi, I. and Sinoimeri, Z. (2002) Poverty in Albania. A Qualitative Assessment. Washington DC: World Bank, Technical Paper 520. de Zwager, N., Gedeshi, I., Germenji, E. and Nikas, C. (2005) Competing for Remittances. Tirana: IOM Tirana.

Ehrenreich, B. and Hochschild, A.R. (2003) Introduction, in Ehrenreich, B. and Hochschild, A. R., (eds) Global Women: Nannies, Maids and Sex Workers in the New Economy. New York: Metropolitan Books, 1-14.

Escrivá, A. (2005) Aged global care chains: a Southern-European contribution to the field. Paper presented at the International Conference on Migration and Domestic Work in Global Perspective, Wassenaar, 26-29 May 2005. 
Accepted Manuscript (AM) of Vullnetari, J. and King, R. (2008) 'Does your granny eat grass?' On mass migration, care drain and the fate of older people in rural Albania. Global Networks 8(2): 139-171

[DOI: 10.1111/j.1471-0374.2008.00189.x][accepted 12 July 2007; first published online 29 February 2008; published April 2008].

Fakiolas, R. (1994) Migration to and from Greece during the last four decades, in Alogoskoufis, G., Kollinzas, T. and Provopoulos, G., (eds) Essays in Honour of Constantine G. Drakatos. Athens: Papazissis, 571-90.

Fakiolas, R. (2003) Regularising undocumented immigrants in Greece: procedures and effects. Journal of Ethnic and Migration Studies, 29(3): 539-61.

Ferrera, M. (1996) The Southern model of welfare in Europe. Journal of European Social Policy, 6(1): 17-37.

Gedeshi, I., Mara, H., Dhimitri, R. and Krisafi, K. (1999) Emigri i elítës intelektuale nga Shqipëria gjatë periudhës së tranzicionit. Tirana: Luarasi.

Glaser, W. (1978) Brain Drain: Emigration and Return. Oxford: Pergamon.

Government of Albania (2005) National Strategy on Migration. Tirana: Albanian Government and International Organisation for Migration.

Gustafson, P. (2001) Retirement migration and transnational lives. Ageing and Society, 21(3): 371-94.

Hall, D. (1994) Albania and the Albanians. London: Pinter Reference.

Hatziprokopiou, P. (2003) Albanian immigrants in Thessaloniki, Greece: processes of economic and social incorporation. Journal of Ethnic and Migration Studies, 29(6): 1033-57.

Hatziprokopiou, P. (2006) Globalisation, Migration and Socio-Economic Change in Contemporary Greece: Processes of Social Incorporation of Albanian and Bulgarian Immigrants in Thessaloniki. Amsterdam: Amsterdam University Press.

Hochschild, A.R. (2001) Global care chains and emotional surplus value, in Hutton, W. and Giddens, A., (eds) On the Edge: Living with Global Capitalism. London: Vintage Books, 130-46.

Hondagneu-Sotelo, P. and Avila, E. (1997) 'I'm here, but I'm there': the meanings of Latina transnational motherhood. Gender and Society, 11(5): 548-71.

INSTAT (2002) The Population of Albania in 2001: Main Results of the Population and Housing Census. Tirana: Instituti i Statistikës.

INSTAT (2004a) Migration in Albania. Tirana: Instituti i Statistikës.

INSTAT (2004b) Albania Census Atlas 2001. Tirana: Instituti i Statistikës. 
Accepted Manuscript (AM) of Vullnetari, J. and King, R. (2008) 'Does your granny eat grass?' On mass migration, care drain and the fate of older people in rural Albania. Global Networks 8(2): 139-171

[DOI: 10.1111/j.1471-0374.2008.00189.x][accepted 12 July 2007; first published online 29 February 2008; published April 2008].

INSTAT (2004c) Population Projections for Albania 2001-2021. Tirana: Instituti i Statistikës.

INSTAT (2004d) Gender Perspectives in Albania. Tirana: Instituti i Statistikës.

King, R. (2003) Across the sea and over the mountains: documenting Albanian migration. Scottish Geographical Journal, 119(3): 283-309.

King, R. (2005) Albania as a laboratory for the study of migration and development. Journal of Southern Europe and the Balkans, 7(2): 133-55.

King, R., Dalipaj, M. and Mai, N. (2006) Gendering migration and remittances: evidence from London and northern Albania. Population, Space and Place, 12(6): 409-34.

King, R. and Mai, N. (2004) Albanian immigrants in Lecce and Modena: narratives of rejection, survival and integration. Population, Space and Place, 10(6): 45577.

King, R. and Vullnetari, J. (2003) Migration and Development in Albania. Brighton: University of Sussex, Development Research Centre on Migration, Globalisation and Poverty, Working Paper $\mathrm{C}_{5}$.

King, R. and Vullnetari, J. (2006) Orphan pensioners and migrating grandparents: the impact of mass migration on older people in rural Albania. Ageing and Society, 26(5): 783-816.

King, R., Warnes, A.M. and Williams, A.M. (1998) International retirement migration in Europe. International Journal of Population Geography, 4(2): 91-111.

King, R., Warnes, A.M. and Williams, A.M. (2000) Sunset Lives: British Retirement Migration to the Mediterranean. Oxford: Berg.

Konidaris, G. (2005) Examining policy response to immigration in the light of interstate relations and foreign policy objectives: Greece and Albania, in King, R., Mai, N. and Schwandner-Sievers, S., (eds) The New Albanian Migration. Brighton: Sussex Academic Press, 64-92.

Kretsi, G. (2005) The uses of origin: migration, power-struggle and memory in southern Albania, in King, R., Mai, N. and Schwandner-Sievers, S., (eds) The New Albanian Migration. Brighton: Sussex Academic Press, 193-212. 
Accepted Manuscript (AM) of Vullnetari, J. and King, R. (2008) 'Does your granny eat grass?' On mass migration, care drain and the fate of older people in rural Albania. Global Networks 8(2): 139-171 [DOI: 10.1111/j.1471-0374.2008.00189.x][accepted 12 July 2007; first published online 29 February 2008; published April 2008].

Kule, D., Mançellari, A., Papapanagos, H., Qirici, S. and Sanfey, P. (2002) The causes and consequences of Albanian emigration during transition: evidence from micro-data. International Migration Review, 36(1): 229-39.

Labrianidis, L. and Hatziprokopiou, P. (2005) The Albanian migration cycle: migrants tend to return to their country of origin after all, in King, R., Mai, N. and Schwandner-Sievers, S., (eds) The New Albanian Migration. Brighton: Sussex Academic Press, 93-117.

Mai, N. (2003) The cultural construction of Italy in Albania and vice versa: migration dynamics, strategies of resistance and politics of mutual self-definition across colonialism and post-colonialism. Modern Italy, 8(1): 77-93.

Moen, P. and Forest, K.B. (1995) Family policies for an ageing society: moving to the twenty-first society. The Gerontologist, 35(6): 825-30.

Nicholson, B. (2004) Migrants as agents of development: Albanian return migrants and micro-enterprise, in Pop, D., (ed.) New Patterns of Labour Migration in Central and Eastern Europe. Cluj Napoca: Public Policy Centre, 94-110.

O'Reilly, K. (2000) The British on the Costa del Sol: Transnational Identities and Local Communities. London: Routledge.

Olwig, K.F. (1999) Narratives of the children left behind: home and identity in globalised Caribbean families. Journal of Ethnic and Migration Studies, 25(2): 267-84.

Papapanagos, H. and Sanfey, P. (2001) Intention to emigrate in transition countries: the case of Albania. Journal of Population Economics, 14(3): 491-504.

Pratsinakis, E. (2004) Aspirations and strategies of Albanian immigrants in Thessaloniki. Journal of Southern Europe and the Balkans, 7(2): 195-212.

Psimmenos, I. and Kassimati, K. (2003) Immigration control pathways: organisational culture and work values of Greek welfare officers. Journal of Ethnic and Migration Studies, 29(2): 337-71.

Reilly, B., Litchfield, J. and Castaldo, A. (2005) Who is most likely to migrate from Albania? Evidence from the Albania Living Standards Measurement Survey. Brighton: University of Sussex Development Research Centre on Migration, Globalisation and Poverty, Briefing No.2. 
Accepted Manuscript (AM) of Vullnetari, J. and King, R. (2008) 'Does your granny eat grass?' On mass migration, care drain and the fate of older people in rural Albania. Global Networks 8(2): 139-171 [DOI: 10.1111/j.1471-0374.2008.00189.x][accepted 12 July 2007; first published online 29 February 2008; published April 2008].

Sjöberg, Ö. (1991) Rural Change and Development in Albania. Boulder: Westview Press.

Trifiletti, R. (1999) Southern European welfare regimes and the worsening position of women. Journal of European Social Policy, 9(1): 49-64.

van Hear, N. (1998) New Diasporas. London: UCL Press.

Vickers, M. (1995) The Albanians: A Modern History. London: I.B. Tauris.

Wallerstein, I. (1979) The Capitalist World Economy. Cambridge: Cambridge University Press.

Wilding, R. (2006) 'Virtual' intimacies? Families communicating across transnational contexts. Global Networks, 6(2): 125-42.

World Bank (1999) Albania: Filling the Vulnerability Gap. Tirana: World Bank, Europe and Central Asia Region.

World Bank (2007) From Red to Gray: The 'Third Transition' of Aging Populations in Eastern Europe and the Former Soviet Union. Washington D.C.: World Bank.

Zinn, D.L. (1996) Adriatic brethren or black sheep? Migration in Italy and the Albanian crisis. European Urban and Regional Studies, 3(3): 241-49.

Zontini, E. (2004) Immigrant women in Barcelona: coping with the consequences of transnational lives. Journal of Ethnic and Migration Studies, 30(6): 1113-44.

\section{Notes}

\footnotetext{
${ }^{1}$ From Primrose Peacock, 'Letter from Albania', October 2005. For further details, besa.wk@btopenworld.com. Thanks to Primrose Peacock for permission to quote from her letter. ${ }^{2}$ However, to some extent these expectations are changing in Italy. Increases in dual-income households and of women in the workforce, combined with the dramatic decline in the birth-rate and the break-up of traditional, spatially contiguous extended families, are making it objectively difficult for older people to receive family care in the ways described. But institutional care facilities have not expanded to fill this void. Instead the preference has arisen for 'family-like' care in the form of the permanent live-in carer (badante), who is often an immigrant woman. See Baldassar (2007: 281-82). 3 The marked gendering of care has been noted in many transnational contexts, including those where migrants' children, rather than their parents, are the ones who remain behind and therefore need 'distant care'. The phenomenon of 'transnational mothering' has already been noted in the literature, especially the writings on the migration of 'third world' women for domestic service in rich countries (Hondagneu-Sotelo and Avila 1997; Olwig 1999; Zontini 2004).

4 We use the word 'generations' here in the plural to dispel the notion of older people as a homogenous category of vulnerable people. A useful distinction - itself simplistic - divides older people into the 'young old' (in their 50s and 6os) and the 'old old' (70s plus). The former are more likely to be physically active, to take care of themselves (and others) and to be able to consider travel and migration options. The old old are more likely to be frail, in need of care, and unable or unwilling to travel or relocate abroad. See Ackers and Dwyer (2002) for further discussion.
} 
Accepted Manuscript (AM) of Vullnetari, J. and King, R. (2008) 'Does your granny eat grass?' On mass migration, care drain and the fate of older people in rural Albania. Global Networks 8(2): 139-171 [DOI: 10.1111/j.1471-0374.2008.00189.x][accepted 12 July 2007; first published online 29 February 2008; published April 2008].

5 The relevant published volumes of the 2001 Census (INSTAT 2002; 2004a; 2004b) do not give district-level figures disaggregated for emigration and internal migration, only the overall residual for all in/out movements. However, Carletto et al. (2004) have disaggregated these two flows by reworking the raw data from the census files. These are the tabulations that we have used for Figure 1a. ${ }^{6}$ Our preference for a qualitative, in-depth interview strategy reflects our research objective of understanding the human and emotional dimensions of Albanian migration, including engaging with the complexities of everyday life and accessing the neglected voices, yet rich knowledges, of older people who are normally sidelined in migration studies. We do not deny the complementary value of numerically large questionnaire studies, of which these have been several - see Arrehag et al. (2005; 2006); Castaldo et al. (2005), based on data from the Albanian Living Standards Measurement Survey; de Zwager et al. (2005); Kule et al. (2002); and Papapanagos and Sanfey (2001). None of these, however, deals with transnational care-giving and the elderly, beyond some reference to remittances in Arrehag et al. (2005) and de Zwager et al. (2005).

7 For accessible descriptions of Albanian economic and family life during the communist era see Hall (1994), Sjöberg (1991) and Vickers (1995).

8 For further evidence on this ambivalence see our parallel paper (King and Vullnetari 2006). The extent to which return has taken place already, or will occur in the future, is subject to a variety of interpretations. Lack of any solid data on return migration obviously does not help here. Amongst studies which stress that return has taken place are Kule et al. (2002), Labrianidis and Hatziprokopiou (2005), and Nicholson (2004). Meanwhile in a large-scale questionnaire study de Zwager et al. (2005) found that 56 per cent of the long-term emigrants surveyed stated a wish to return. On the basis of these survey data de Zwager et al. proceed to make various projections on migration, remittance and development trends over the coming years. However, it is vitally important to look carefully at the wording of such questions: expressing a wish to return can be very different to having a concrete intention to return, and even intention may be far removed from the actualisation of that intention. See our discussion of return in King (2005) and King and Vullnetari (2003).

9 For a detailed analysis of Thessaloniki as a setting for Albanian (and other) immigration see Hatziprokopiou (2006).

10 When the wife joins her husband's household, although she brings dowry (in-kind) with her, she is not considered immediately as an equal shareholder in the accumulated capital and property that she finds in her new home. On the other hand, positions are reversed when the husband joins his wife's family (often when her parents have no sons). Furthermore, in such cases men are not seen as being in control and thus a certain degree of emasculation takes place. These positions in turn decide those of the parents-in-law. Risking oversimplification, these gendered roles are stronger in the north of the country and more so in rural areas, but change can be noted over time.

${ }^{11}$ Cohort survival rates (the tendency for women to live longer than men) would indicate a surplus of women at this age, not men. Women are also likely to survive their husbands, and therefore be 'available' for migration as widows, because of the significant age gap between spouses. The peak age for marriage for men is 26 and for women 20: these peaks have been remarkably stable over time. This gap - larger than most other European countries - suggests patriarchal social structures, reinforced by patrilinear and patrilocal practices. See INSTAT (2004b).

${ }_{12}$ Ethnic-Greek status is by no means a fixed and simply-defined ethnic category in Albania. For one thing, numbers are fiercely contested: Greek authorities claim up to 300,000, Albanian sources suggest around 60,000. Anthropological studies of villages and rural districts in south Albania have explored some of the complexities and ambiguities of ethnic, religious and linguistic identities there. Since 1990 ethnic-Greek identity has obvious 'added-value' because of the privileges granted by the Greek government (free entry, less discrimination in Greek society, access to pensions etc.), with the result that such an identity becomes 'instrumentalised' by some who may have tenuous claims. See de Rapper (2005) and Kretsi (2005). 